\title{
Uremia Suppresses Immune Signal-Induced CYP27B1 Expression in Human Monocytes
}

\author{
Liesbeth Viaene $^{\mathrm{a}}$ Pieter Evenepoel $^{\mathrm{a}} \quad$ Björn Meijers $^{\mathrm{a}} \quad$ Dirk Vanderschueren $^{\mathrm{b}, \mathrm{c}}$ \\ Lut Overbergh $^{\mathrm{b}}$ Chantal Mathieu $^{\mathrm{b}}$ \\ Departments of ${ }^{a}$ Nephrology, ${ }^{b}$ Clinical and Experimental Endocrinology, and ${ }^{\mathrm{C}}$ Laboratory Medicine, KU Leuven, \\ UZ Gasthuisberg, Leuven, Belgium
}

\section{Key Words}

Monocytes · Local CYP27B1 regulation • Uremia · FGF23 •

$p$-Cresyl sulfate $\cdot$ Indoxyl sulfate

\begin{abstract}
Background: Local production of 1,25-dihydroxyvitamin D $\left(1,25(\mathrm{OH})_{2} \mathrm{D}\right)$ regulated by the CYP27B1 enzyme in monocytes contributes to the immunomodulatory effects of vitamin D. Uremia suppresses renal CYP27B1, but its impact on monocytic CYP27B1 is incompletely understood. The present study aimed to elucidate this issue and to define the pathogenic role of $p$-cresyl sulfate (PCS), indoxyl sulfate (IndS), and fibroblast growth factor 23 (FGF23). Methods: Resting or immune (interferon- $\gamma+$ lipopolysaccharide)stimulated THP1 cells and monocytes, isolated from healthy donors, were cultured in the presence of either healthy serum, uremic serum, PCS, IndS or FGF23. RNA expression levels for CYP27B1 and cytokines were quantified by RT-PCR and enzymatic CYP27B1 activity was measured $24 \mathrm{~h}$ after incubation. Results: Culturing THP1 cells or human monocytes in the presence of uremic serum led to higher inflammatory cytokine and CYP27B1 expression. Immune signalinduced CYP27B1 expression and activity, conversely, was impaired in the presence of uremic serum. Similar effects were observed in the presence of FGF23, although significance was reached in immune-stimulated cells only. PCS and IndS failed to show any effect. Conclusions: Monocytic
\end{abstract}

baseline CYP27B1 expression is increased in uremia, probably reflecting the microinflammatory state. Immune signal-induced CYP27B1 expression, conversely, is impaired in uremic conditions. Elevated FGF23 levels, but not PCS and IndS, may account, at least partly, for the dysregulation of monocytic CYP27B1 in uremia and, as such, may contribute to the high cardiovascular and infectious burden in chronic kidney disease.

Copyright $\odot 2012$ S. Karger AG, Basel

\section{Introduction}

The vitamin D system is crucial for the maintenance of mineral and bone metabolism and is severely disturbed in chronic kidney disease (CKD) [1]. The classical actions of vitamin $\mathrm{D}$ are established by circulating 1,25-dihydroxyvitamin $\mathrm{D}$ (calcitriol; $\left.1,25(\mathrm{OH})_{2} \mathrm{D}\right)$. The active hormone $1,25(\mathrm{OH})_{2} \mathrm{D}$ is derived from vitamin $\mathrm{D}$ after two hydroxylation steps. The 25-hydroxylation step takes place in the liver; the second $1 \alpha$-hydroxylation step generates the bioactive metabolite $1,25(\mathrm{OH})_{2} \mathrm{D}$. A single enzyme, CYP27B1, controls the rate-limiting step in the production of $1,25(\mathrm{OH})_{2} \mathrm{D}$. Renal CYP27B1 activity is significantly impaired in CKD [1].

In recent years, the pleiotropic effects of vitamin $\mathrm{D}$ in organ systems outside bone and calcium metabolism have gathered much attention, in particular its cardiopro-

\section{KARGER}

Fax +4161306 1234 E-Mail karger@karger.ch www.karger.com

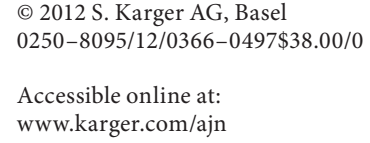

Dr. L. Overbergh

Clinical and Experimental Endocrinology

KU Leuven, UZ Gasthuisberg

Herestraat 49, Box 902, BE-3000 Leuven (Belgium)

E-Mail lut.overbergh@med.kuleuven.be 
tective and immune-modulating effects. These pleiotropic effects are highly dependent on the efficient autocrine/paracrine synthesis of $1,25(\mathrm{OH})_{2} \mathrm{D}$ in various extrarenal tissues, including monocytes. Both low 25-hydroxyvitamin $\mathrm{D}(25(\mathrm{OH}) \mathrm{D})$ and low $1,25(\mathrm{OH})_{2} \mathrm{D}$ levels are associated with increased morbidity and mortality in CKD. Interestingly, this association is even stronger for 25(OH)D [2-5]. The latter finding, together with the observation that anephric patients are able to convert $25(\mathrm{OH}) \mathrm{D}$ to $1,25(\mathrm{OH})_{2} \mathrm{D}$, fuelled the thesis that locally produced $1,25(\mathrm{OH})_{2} \mathrm{D}$ explains the positive association between 25(OH)D levels and health benefits $[6,7]$.

At present, knowledge about the impact of CKD on extrarenal vitamin D metabolism is limited. In the present study, we focused on the vitamin $\mathrm{D}$ metabolism in monocytes. These cells express both CYP27B1 and the vitamin $\mathrm{D}$ receptor (VDR) and locally produce $1,25(\mathrm{OH})_{2} \mathrm{D}$ to stimulate innate immune responses and modulate adaptive immunity [8]. Monocytes are critical components in the innate immune system and also play an important role in atherogenesis. A dysregulated vitamin D metabolism in monocytes may thus be speculated to contribute to the increased infectious and cardiovascular burden in CKD.

Elevated serum levels of the phosphaturic hormone fibroblast growth factor 23 (FGF23) and the protein-bound uremic retention molecules $p$-cresyl sulfate (PCS) and indoxyl sulfate (IndS) are associated with cardiovascular and infectious mortality and morbidity in CKD [9-13]. These poor outcomes may be mediated by a dysregulated vitamin D metabolism in monocytes. Indeed, PCS and IndS have previously been shown to activate leucocytes $[14,15]$ and FGF23 is a well-established regulator of renal vitamin D metabolism. FGF23 not only inhibits CYP27B1 activity but also stimulates the degradation of $1,25(\mathrm{OH})_{2} \mathrm{D}$ by CYP24A1 [16]. High FGF23 levels actually are the major cause of low circulating $1,25(\mathrm{OH})_{2} \mathrm{D}$ levels in CKD [17]. Recent evidence indicates that FGF23 may also have so-called 'off-target' effects [18]. The present study aimed to elucidate the impact of uremia on vitamin $\mathrm{D}$ metabolism in monocytes and to define the regulatory role of PCS, IndS, and FGF23.

We first show that monocytes from hemodialysis patients have an increased expression of CYP27B1. Proinflammatory mediators are most likely involved in this upregulation. Immune signal-induced CYP27B1 expression, conversely, is impaired in uremic conditions. We finally provide evidence that FGF23, but not PCS and IndS, accounts, at least partly, for the dysregulation of monocytic CYP27B1 in uremia.

\section{Methods}

\section{Cell Culture Conditions}

Human acute monocytic leukemia THP1 monocytes (American Type Culture Collection, Rockville, Md., USA) were grown in Roswell Park Memorial Institute (RPMI) 1640, supplemented with $100 \mu \mathrm{M} \beta$-mercaptoethanol, 10\% fetal calf serum (FCS), and antibiotics (100 U/ml penicillin and $100 \mu \mathrm{g} / \mathrm{ml}$ streptomycin). THP1 cells were stimulated with $100 \mathrm{U} / \mathrm{ml}$ human recombinant interferon- $\gamma$ (IFN $\gamma$ ) and $10 \mu \mathrm{g} / \mathrm{ml}$ lipopolysaccharide (LPS).

Human peripheral blood mononuclear cells were isolated by Ficoll gradient from buffy coats obtained from healthy blood donors or from blood of randomly selected hemodialysis patients (collected in EDTA tubes). Monocytes were obtained using negative selection with the Monocyte Isolation Kit II following the supplier's protocol (Miltenyi Biotec, Amsterdam, the Netherlands). Typically, $>90 \%$ purity of monocytes was obtained by the purification method as determined by fluorescence-activated cell sorting analysis for CD14. Isolated monocytes $\left(1 \times 10^{6}\right.$ cells $\left./ \mathrm{ml}\right)$ were cultured in RPMI-1640 with 10\% FCS and antibiotics (100 $\mathrm{U} / \mathrm{ml}$ penicillin and $100 \mu \mathrm{g} / \mathrm{ml}$ streptomycin) and stimulated with $12.5 \mathrm{U} / \mathrm{ml} \mathrm{IFN} \gamma$ and $100 \mathrm{ng} / \mathrm{ml}$ LPS. PCS, IndS, FGF23 or serum was added to the cell cultures at the indicated concentrations and further incubated as indicated. Monocytes from stable hemodialysis patients were isolated in a similar manner.

\section{Experimental Conditions}

\section{Serum}

In a subset of experiments, growth medium was supplemented with $30 \% \mathrm{vol} / \mathrm{vol}$ healthy or uremic serum. We used pooled serum from 14 maintenance hemodialysis patients; sampling was done just before starting the dialysis session. All hemodialysis patients routinely received cholecalciferol therapy. For the healthy serum, we pooled serum of 10 healthy volunteers, recruited from the medical staff.

Uremic Retention Molecules and FGF23

PCS was synthesized as potassium salt according to Feigenbaum and Neuberg [19] and as previously described [20]. Identity and purity (>99\%) were performed using nuclear magnetic resonance, high-performance liquid chromatography (HPLC) and gas chromatography-mass spectrometry. Presence of endotoxin in the final product was excluded using the Limulus Amebocyte Lysate (LAL) test (Cambrex-Lonza, Verviers, Belgium). Stock solutions were prepared in RPMI-1640 on the same day and filtrated just before application (Filtropur $0.2 \mathrm{mM}$ ). PCS was added to the cell cultures in the following concentrations: 1 and $0.1 \mathrm{mM}$. As PCS is synthesized as a potassium salt, growth medium supplemented with potassium chloride served as control.

IndS was purchased from Sigma. Presence of endotoxin was excluded using the LAL test. Stock solutions were prepared in RPMI-1640 on the same day and filtrated just before application (Filtropur $0.2 \mathrm{mM}$ ). IndS was added to the cell cultures in the following concentrations: 1 and $0.1 \mathrm{mM}$. Recombinant human FGF23 (R\&D Systems, Minneapolis, Minn., USA) was added to the cell cultures in the following concentrations: 1 and $5 \mathrm{ng} / \mathrm{ml}$.

RNA Extraction, cDNA Synthesis, and Real-Time RT-PCR

Cells were harvested and pooled, centrifuged at $930 \mathrm{~g}$ for $5 \mathrm{~min}$, and resuspended in $200 \mu \mathrm{l}$ phosphate-buffered saline 
Table 1. Primer sequences

\begin{tabular}{|c|c|}
\hline Target & Sequence $\left(5^{\prime}-3^{\prime}\right)$ \\
\hline \multicolumn{2}{|l|}{ RPL27 } \\
\hline FW & TGTCGTCAATAAGGATGTCTTCAGA \\
\hline RV & TGCCTGTCTTGTATCTCTCTTCAAA \\
\hline \multicolumn{2}{|l|}{$\beta_{2}-\mathrm{MG}$} \\
\hline FW & TGCCGTGTGAACCATGTGA \\
\hline RV & CCAAATGCGGCATCTTCAA \\
\hline $\mathrm{TP}$ & TGATGCTGCTTACATGTCTCGATCCCACT \\
\hline \multicolumn{2}{|r|}{ 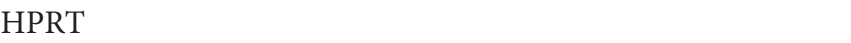 } \\
\hline FW & TGTAGGATATGCCCTTGACTATA \\
\hline RV & CAATAGGACTCCAGATGTTTCCA \\
\hline $\mathrm{TP}$ & TGGAAAAGCAAAATACAAAGCCTAAGATGAG \\
\hline \multicolumn{2}{|c|}{ CYP27B1 } \\
\hline FW & CCCAGATCCTAACACATTTTGAGG \\
\hline RV & AAAGGGTGATGATGACAGTCTCTTTC \\
\hline $\mathrm{TP}$ & ACCCAAGACCCGGACTGTCCTGGT \\
\hline \multicolumn{2}{|c|}{$24 \alpha$-Hydroxylase } \\
\hline FW & TATCGCGACTACCGCAAAGA \\
\hline $\mathrm{RV}$ & CGGCCAAGACCTCATTGATT \\
\hline $\mathrm{TP}$ & TCCGGACCCGCTGCCAGTCTT \\
\hline \multicolumn{2}{|r|}{ 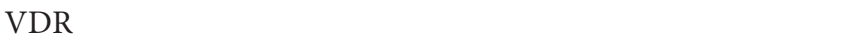 } \\
\hline FW & TGGCTTTCACTTCAATGCTATGA \\
\hline RV & CGTCGGTTGTCCTTGGTGAT \\
\hline $\mathrm{TP}$ & AAGGCTGCAAAGGCTTCTTCAGGCG \\
\hline \multicolumn{2}{|r|}{ 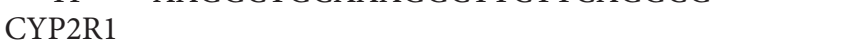 } \\
\hline FW & CAG-CAT-TGC-TTC-AGA-GGT-TTC-A \\
\hline RV & TTC-AGC-GTC-TTT-CAG-CAC-AGA \\
\hline \multicolumn{2}{|c|}{ CYP27A1 } \\
\hline FW & GAT-CCA-TCG-GGT-TAA-TGT-TCC-A \\
\hline RV & CAA-AGG-AAA-AGA-TGG-CAT-TCC-A \\
\hline \multicolumn{2}{|r|}{ (2) } \\
\hline FW & TACCTGAGCTCGCCAGTGAA \\
\hline RV & CAGAGGTCCAGGTCCTGGAA \\
\hline \multicolumn{2}{|r|}{ (1) } \\
\hline FW & CACCGGGAACGAAAGAGAAG \\
\hline RV & CCCAGGGAGAAGGCAACTG \\
\hline $\mathrm{TP}$ & ССTTCTCCACAAGCHCCTTCGGT \\
\hline \multicolumn{2}{|r|}{ ences } \\
\hline FW & TCTTCTCGAACCCCGAGTGA \\
\hline RV & CCTCTGATGGCACCACCAG \\
\hline TP & TAGCCCATGTTGTAGCAAACCCTCAAGCT \\
\hline \multicolumn{2}{|r|}{ 2010 } \\
\hline FW & GGGAACTGTATCCCACAATGATC \\
\hline RV & CTGGCGGCCACAGGAA \\
\hline \multicolumn{2}{|r|}{ ( } \\
\hline RW & AGCCTTCAGCCCCACCTT \\
\hline $\mathrm{RV}$ & ACCCATTCCACATTCAAGATGAC \\
\hline
\end{tabular}

$\mathrm{FW}=$ Forward primer $\mathrm{RV}=$ reverse primer; $\mathrm{TP}=$ TaqMan probe.

(PBS). Total RNA was extracted $\left(1 \times 10^{6}\right.$ cells per condition $)$ using the High Pure RNA Isolation Kit (Roche, Vilvoorde, Belgium). cDNA synthesis was performed as previously described [21]. RT-PCR was performed in a volume of $10 \mu$ l containing 0.5 nmol forward and reverse primers (table 1), $5 \mu$ l Fast SYBR ${ }^{\circledR}$ Green Master Mix (Applied Biosystems, Foster City, Calif., USA) or TaqMan Mix (Applied Biosystems) and $0.2 \mu \mathrm{l}$ cDNA. The samples were assayed on an ABI-Prism 7500 Fast (Applied Biosystems). The relative expression level of the gene of interest was calculated using the $2^{-\Delta \Delta \mathrm{Ct}}$ method by normalizing to the geometrical mean of three stable housekeeping genes - ribosomal protein L27 (RPL27), $\beta_{2}$-microglobulin ( $\beta_{2}-\mathrm{MG}$ ) and hypoxanthine phosphoribosyltransferase (HPRT) - and presented as fold increase relative to control.

Measurement of CYP27B1 Enzymatic Activity

THP1 cells $\left(6 \times 10^{6}\right.$ cells/well $)$ or monocytes $\left(6 \times 10^{6}\right.$ cells/ well) were incubated during $24 \mathrm{~h}$ in RPMI-1640, supplemented with either FCS, healthy serum or uremic serum, with or without stimulation with the combination of IFN $\gamma$ and LPS. After $24 \mathrm{~h}$, medium was removed and replaced by serum-free RPMI-1640 containing $0.1 \%$ fatty acid free BSA (Sigma, tested for absence of bovine vitamin $\mathrm{D}$ binding protein) and incubated for $0.5,1.5$ or $3 \mathrm{~h}$ with 30 or $60 \mathrm{ng} / \mathrm{ml} 25(\mathrm{OH}) \mathrm{D}$. Cells and media were pooled and sonicated. After centrifugation, sample $1,25(\mathrm{OH})_{2} \mathrm{D}$ concentrations were measured using the liquid chromatography tandem mass spectrometry method as previously described [22]. The limit of detection was $6 \mathrm{pg} / \mathrm{ml}$.

Measurement of Intracellular PCS and IndS Concentration

Isolated monocytes were seeded in cell culture dishes at a cell density of $6 \times 10^{6}$ cells/well. PCS or IndS $(1 \mathrm{mmol} / \mathrm{l})$ was added to the cell cultures, and uptake into the cells was examined after 1 and $24 \mathrm{~h}$. The cells were washed in PBS (repeated three times) to remove the medium. Thereafter, cells were sonicated. Cellular extract (in PBS) was applied on a SunFire C18 column of Waters Alliance 2695 HPLC (Waters, Zellik, Belgium). The amount of intracellular PCS or IndS was determined by HPLC as previously described [23]. The detection limit of the HPLC is $1.8 \mu \mathrm{M}$ (PCS) and $3.2 \mu \mathrm{M}$ (IndS) allowing us to detect even minimal $(<1 \%)$ uptake.

\section{Measurement of $25(\mathrm{OH}) \mathrm{D}, 1,25(\mathrm{OH})_{2} \mathrm{D}$ and FGF23 \\ (Pooled Sera)}

Serum concentrations $25(\mathrm{OH}) \mathrm{D}$ and $1,25(\mathrm{OH})_{2} \mathrm{D}$ were measured using respectively radioimmunoassay and liquid chromatography tandem mass spectrometry as previously described [22, 24]. FGF23 was measured using a commercial ELISA kit (Kainos, Tokyo, Japan).

\section{Statistical Analysis}

For all experiments, comparisons were performed by Student's t test or one-way ANOVA with Duncan post hoc comparison, whenever appropriate. Differences were considered significant at $\mathrm{p}<0.05$.

\section{Results}

Uremia Leads to Increases in CYP27B1 Expression in Human Monocytes

Monocytes were isolated via negative selection to avoid activation and were cultured for $24 \mathrm{~h}$ in the absence of any stimulus. In these baseline circumstances, 
Fig. 1. CYP27B1 and VDR expression in monocytes from healthy volunteers (HV) and hemodialysis patients (HD). Monocytes were cultured for $24 \mathrm{~h}$. CYP27B1 and VDR mRNA levels were quantified by real-time RT-PCR and normalized to the geometric mean of RPL27, HPRT, and $\beta_{2}$ MG. Each bar represents the mean of four independent experiments for each group ( \pm SEM $) .{ }^{* *} \mathrm{p}<0.01$ vs. monocytes from healthy volunteers; ${ }^{*} \mathrm{p}=0.03$ vs. monocytes from healthy volunteers.
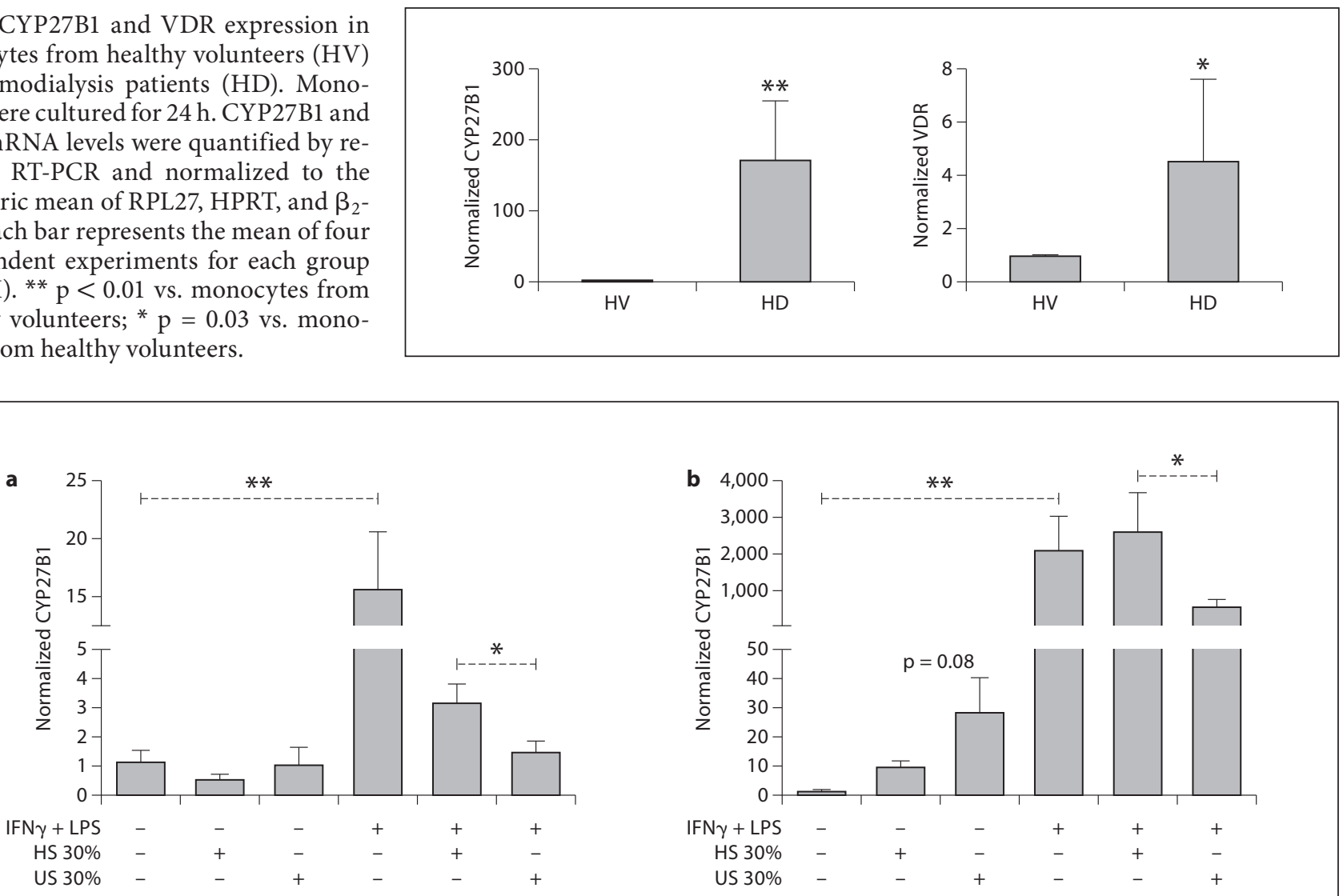

Fig. 2. a Expression of CYP27B1 mRNA in THP1 cells. THP1 cells were cultured for $24 \mathrm{~h}$ with or without IFN $\gamma+$ LPS stimulation (IFN $\gamma 100 \mathrm{U} / \mathrm{ml}$ and LPS $10 \mu \mathrm{g} / \mathrm{ml}$ ), in the presence/absence of $30 \%$ healthy serum (HS) or uremic serum (US). CYP27B1 mRNA levels were quantified by real-time RT-PCR and normalized to the geometric mean of three housekeeping genes (RPL27, HPRT and $\left.\beta_{2}-\mathrm{MG}\right)$. Each bar represents the mean of three independent experiments, each performed in quadruplicate $( \pm S E M)$. b Expression of CYP27B1 mRNA in monocytes. Monocytes were cultured for $24 \mathrm{~h}$ with or without IFN $\gamma+$ LPS stimulation (IFN $\gamma 12.5 \mathrm{U} / \mathrm{ml}$ and LPS $100 \mathrm{ng} / \mathrm{ml}$ ), in the presence/absence of 30\% healthy serum (HS) or uremic serum (US). CYP27B1 mRNA levels were quantified by real-time RT-PCR and normalized to the geometric mean of three housekeeping genes (RPL27, HPRT and $\beta_{2}-M G$ ). Each bar represents the mean of four independent experiments, each performed in triplicate ( \pm SEM). One-way ANOVA statistics were used with significant Duncan post hoc comparison marked with an asterisk. ${ }^{*} \mathrm{p}<0.01 ;{ }^{* *} \mathrm{p}<0.001$.
CYP27B1 expression was 143-fold higher in monocytes from hemodialysis patients as compared to monocytes from healthy controls ( $p=0.002$; fig 1$)$. Of note, also VDR expression was higher in monocytes from hemodialysis patients $(\mathrm{p}=0.03)$. CYP24 mRNA levels were below the limit of detection in both monocytes from hemodialysis patients and from healthy controls.

To evaluate whether this stimulation was due to circulating factors, THP1 cells as well as monocytes from healthy volunteers were exposed to control serum or to serum from hemodialysis patients. Uremic serum did not significantly alter the expression levels of CYP27B1 in resting THP1 cells (fig. 2a) nor resting, cultured CD14+ monocytes from healthy human subjects, although in the latter a trend for increased expression was present (25fold, $\mathrm{p}=0.08$ ) (fig. $2 \mathrm{~b}$ ) as compared to monocytes cultured in the presence of $30 \%$ control human serum. Of note, healthy serum pools contained $63 \pm 3.8 \mathrm{pg} / \mathrm{ml}$ $1,25(\mathrm{OH})_{2} \mathrm{D}$ and $30.6 \pm 1.1 \mathrm{ng} / \mathrm{ml} 25(\mathrm{OH}) \mathrm{D}$. Uremic serum pools had significantly lower $1,25(\mathrm{OH})_{2} \mathrm{D}$ levels, whereas $25(\mathrm{OH}) \mathrm{D}$ levels were not different (table 2). Other biochemical characteristics of the uremic and healthy serum pools are shown in table 2. 


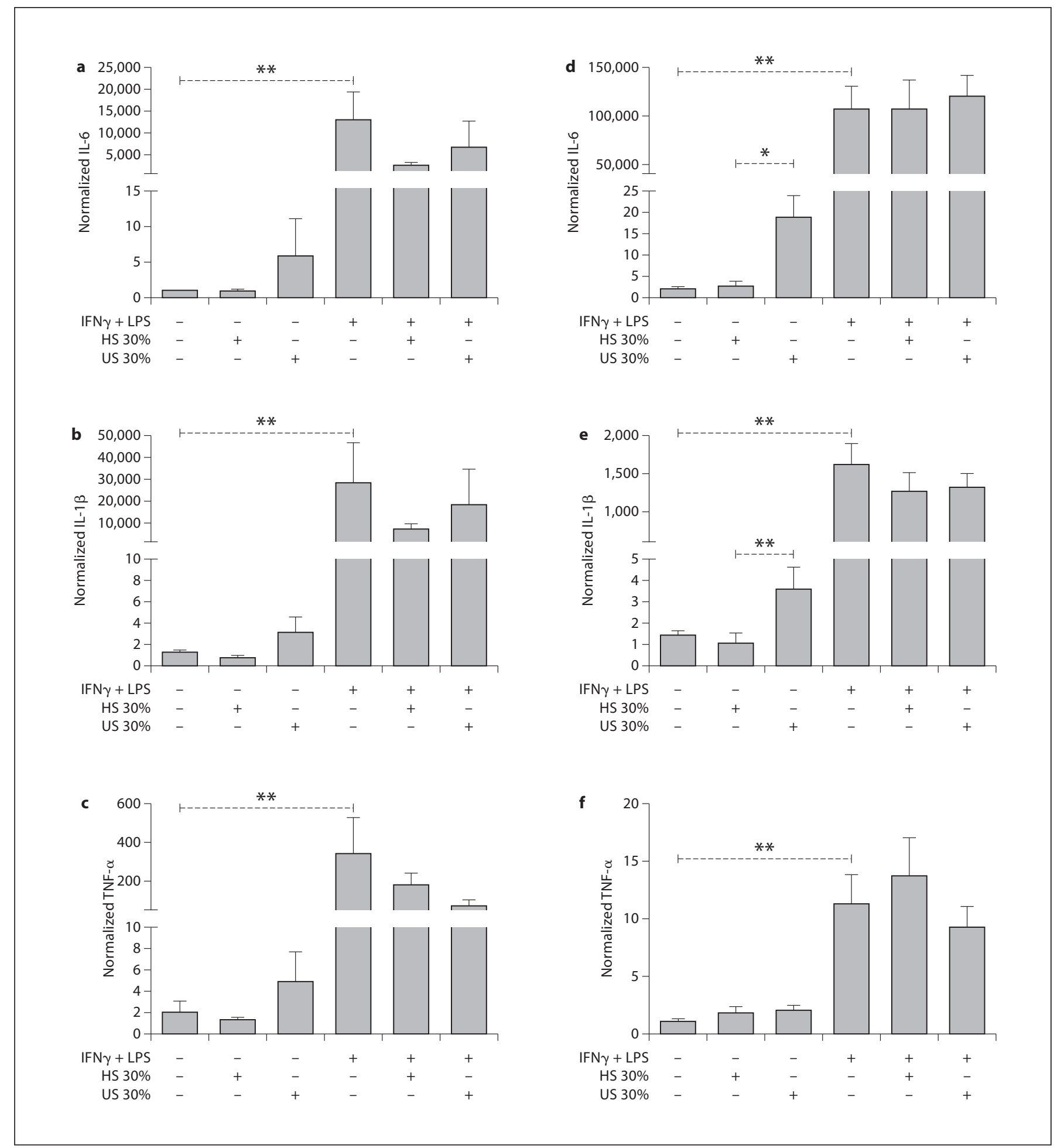

Fig. 3. Expression of IL-6, IL-1 $\beta$ and TNF- $\alpha$ mRNA levels in THP1 cells $(\mathbf{a}-\mathbf{c})$ or monocytes $(\mathbf{d}-\mathbf{f})$. Monocytes and THP1 cells were cultured for $24 \mathrm{~h}$ with or without IFN $\gamma+$ LPS stimulation, in the presence/absence of $30 \%$ healthy serum (HS) or uremic serum (US). IL-6, IL- $1 \beta$ and TNF- $\alpha$ mRNA levels were quantified by real-time RT-PCR and normalized to the geometric mean of three housekeeping genes (RPL27, HPRT and $\beta_{2}-\mathrm{MG}$ ). Each bar represents the mean of four independent experiments, each performed in triplicate $( \pm S E M)$. One-way ANOVA statistics were used with significant Duncan post hoc comparison marked with an asterisk. ${ }^{*} \mathrm{p}<0.01 ;{ }^{* *} \mathrm{p}<0.001$. 
Fig. 4. Effects of IFN $\gamma$ and LPS on CYP27B1 activity in THP1 (a) and monocytes (b). Cells were incubated during $24 \mathrm{~h}$ in the presence of healthy serum (closed circles) or uremic serum (open circles), $30 \mathrm{ng} / \mathrm{ml} 25(\mathrm{OH}) \mathrm{D}$ was included for the final $0.5,1.5$ or $3 \mathrm{~h}$, as indicated on the $\mathrm{y}$ axis. Data are shown as concentration of $1,25(\mathrm{OH})_{2} \mathrm{D}(\mathrm{pg} / \mathrm{ml})$ in stimulated cells. Similar results were obtained after incubation with $60 \mathrm{ng} / \mathrm{ml}$ 25(OH)D (data not shown). The dashed line represents the limit of detection $(6 \mathrm{pg} / \mathrm{ml}) . \mathrm{p}=0.03$ : $1,25(\mathrm{OH})_{2} \mathrm{D}$ production in uremic versus healthy serum.

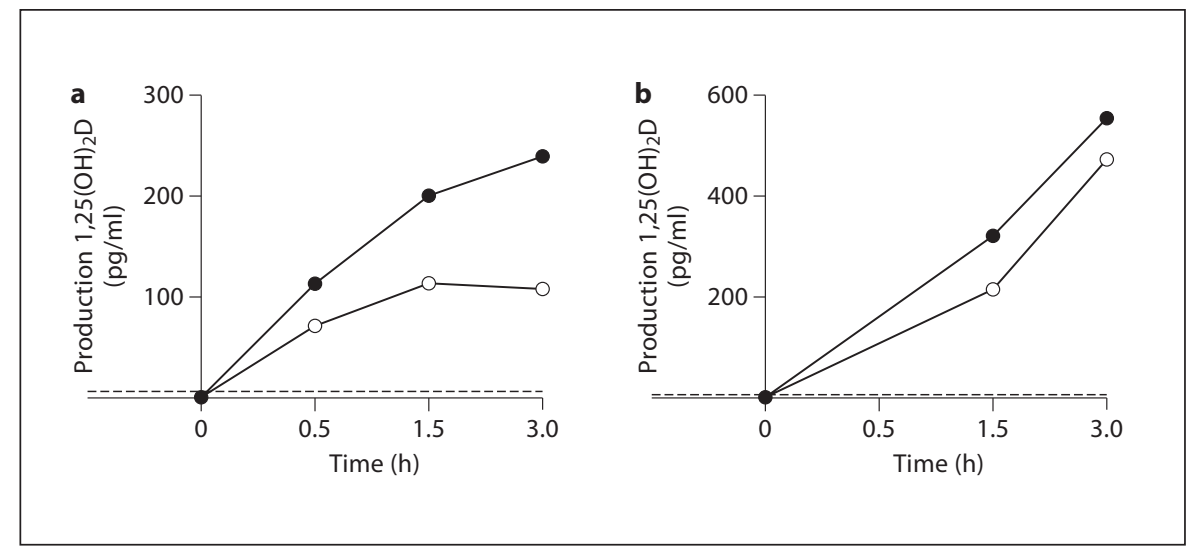

Table 2. Biochemical characteristics of serum pools

\begin{tabular}{lccc}
\hline & $\begin{array}{l}\text { Healthy } \\
\text { serum pool }\end{array}$ & $\begin{array}{l}\text { Uremic } \\
\text { serum pool }\end{array}$ & p value \\
\hline Urea nitrogen, mg/dl & $28.4 \pm 2.4$ & $141.8 \pm 20.6$ & $<0.0001$ \\
Creatinine, mg/dl & $1.0 \pm 0.07$ & $8.4 \pm 0.9$ & $<0.0001$ \\
Calcium, mg/dl & $9.4 \pm 0.3$ & $9.0 \pm 0.2$ & 0.003 \\
Phosphate, mg/dl & $3.3 \pm 0.1$ & $4.6 \pm 0.3$ & $<0.0001$ \\
Albumin, g/l & $44.4 \pm 2.2$ & $35.9 \pm 2.5$ & $<0.0001$ \\
CRP, mg/l & $1.8 \pm 1.1$ & $14.3 \pm 4.4$ & $<0.0001$ \\
PTH, ng/l & $30.1 \pm 7.0$ & $351.8 \pm 128.4$ & $<0.0001$ \\
Calcidiol, ng/l & $30.6 \pm 1.1$ & $27.6 \pm 1.8$ & 0.06 \\
Calcitriol, pg/ml & $63.0 \pm 3.8$ & $31.0 \pm 2.2$ & $<0.0001$ \\
FGF23, pg/ml & $32.0 \pm 4.0$ & $2,126.0 \pm 645.0$ & $<0.0001$ \\
\hline
\end{tabular}

\section{Uremic Serum Carries Proinflammatory Signals for}

Human Monocytes

In THP1 cells, interleukin (IL)-6, IL-1 $\beta$ and tumor necrosis factor- $\alpha$ (TNF- $\alpha$ ) expression following exposure to uremic serum showed a non-significant increase as compared to healthy serum (fig. 3a-c). In CD14+ monocytes from healthy human subjects, this increase reached statistical significance for IL-6 (12-fold, $\mathrm{p}=0.01)$ and IL-1 $\beta$ (5-fold, $\mathrm{p}=0.007$ ) (fig. $3 \mathrm{~d}-\mathrm{f}$ ). When monocytes were stimulated with a combination of IFN $\gamma$ and LPS, uremic serum did not induce an additional inflammatory response (fig. 3).

\section{Uremic Serum Blunts Immune Signal-Induced}

Upregulation of CYP27B1 in Human Monocytes

THP1 cells were stimulated by a combination of IFN $\gamma$ and LPS, leading to inflammatory stimulation of both toll-like receptor (TLR)-4 and TLR-2/1 pathways, to induce CYP27B1 expression. We indeed observed a 19-fold

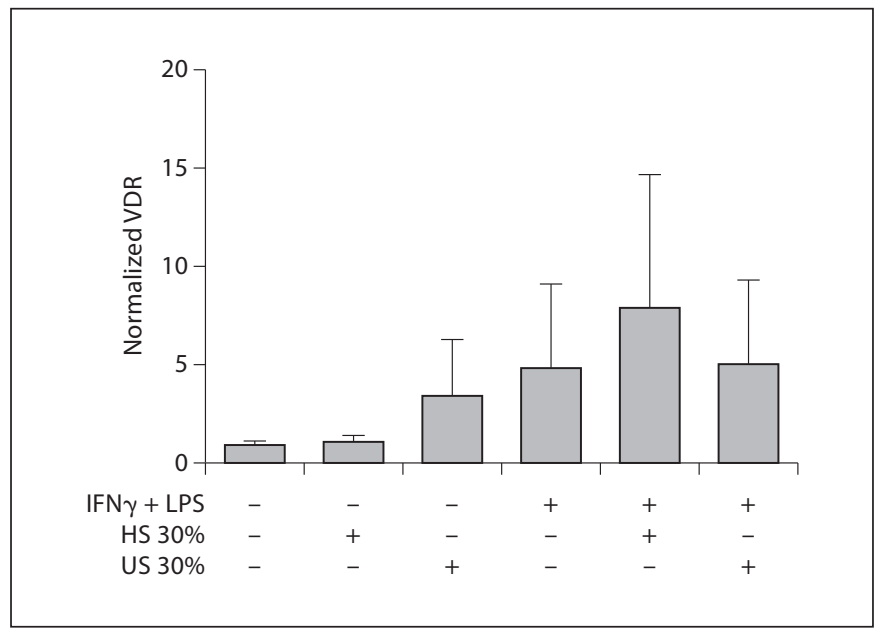

Fig. 5. Expression of VDR mRNA in monocytes. Monocytes were cultured for $24 \mathrm{~h}$ with or without IFN $\gamma+$ LPS stimulation (IFN $\gamma$ $12.5 \mathrm{U} / \mathrm{ml}$ and LPS $100 \mathrm{ng} / \mathrm{ml}$ ), in the presence/absence of $30 \%$ healthy serum (HS) or uremic serum (US). VDR mRNA levels were quantified by real-time RT-PCR and normalized to the geometric mean of three housekeeping genes (RPL27, HPRT and $\beta_{2}$ $M G)$. Each bar represents the mean of four independent experiments, each performed in triplicate ( \pm SEM).

induction of CYP27B1 ( $\mathrm{p}<0.001$ vs. control THP1 cells). In the presence of $30 \%$ uremic serum, CYP27B1 induction was significantly blunted (2-fold inhibition, $\mathrm{p}=0.02$ ) (fig. 2a). Differentiation of healthy human monocytes by addition of IFN $\gamma$ and LPS resulted in a 2,000-fold upregulation of CYP27B1 expression after $24 \mathrm{~h}$ of culture $(\mathrm{p}=$ 0.0002 , as compared to baseline control monocytes). In the presence of $30 \%$ uremic serum this CYP27B1 upregulation was impaired, compared to IFN $\gamma+$ LPS-stimulated monocytes in the presence of $30 \%$ healthy serum (2-fold inhibition, $\mathrm{p}=0.01$ ) (fig. 2b). These changes in CYP27B1 


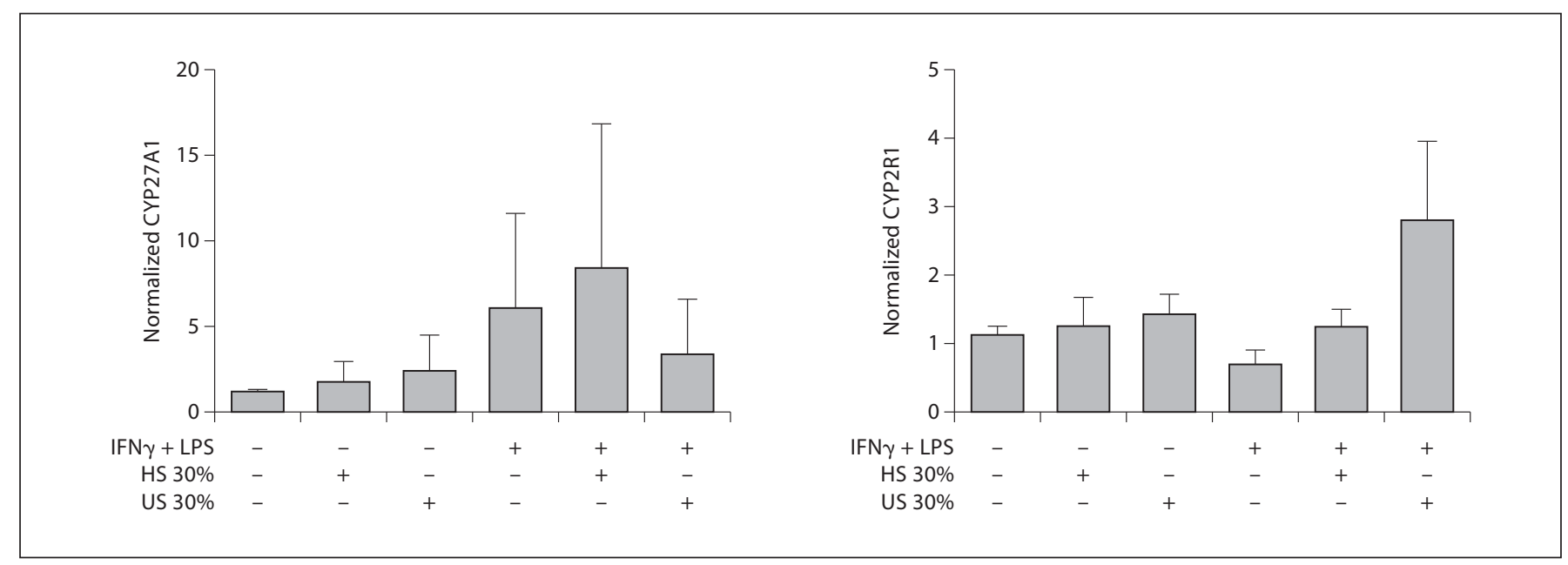

Fig. 6. Expression of CYP27A1 and CYP2R1 mRNA in monocytes. Monocytes were cultured for $24 \mathrm{~h}$ with or without IFN $\gamma+$ LPS stimulation (IFN $\gamma 12.5 \mathrm{U} / \mathrm{ml}$ and LPS $100 \mathrm{ng} / \mathrm{ml}$ ), in the presence/absence of $30 \%$ healthy serum (HS) or uremic serum (US). CYP27A1 and CYP2R1 mRNA levels were quantified by real-time

mRNA levels were paralleled by changes in CYP27B1 activity. Indeed, a low enzymatic activity was measured in resting THP1 cells and monocytes, while a clear induction of enzymatic activity, measured by the conversion of added $25(\mathrm{OH}) \mathrm{D}$ into $1,25(\mathrm{OH})_{2} \mathrm{D}$, was observed upon incubation with the combination of IFN $\gamma$ and LPS. In uremic conditions, this induction of enzymatic activity was clearly blunted ( $\mathrm{p}=0.03)$ (fig. 4).

VDR and the 25-hydroxylase enzyme (CYP2R1 and CYP27A1) expression was observed in monocytes in resting conditions. The major $1,25(\mathrm{OH})_{2} \mathrm{D}$-degrading enzyme, 24-hydroxylase (CYP24A1), conversely, was below the limit of detection. The expression of none of these genes involved in the vitamin D metabolism was induced by IFN $\gamma$ and LPS or uremic serum (fig. 5, 6).

\section{Effect of FGF23 on CYP27B1 Expression in Healthy Monocytes}

FGF23 concentrations in the uremic serum pools amounted to $2,126 \pm 645 \mathrm{pg} / \mathrm{ml}$ and were significantly higher than in the healthy serum pool $(32 \pm 4 \mathrm{pg} / \mathrm{ml}$; $\mathrm{p}<0.0001$ ). THP1 cells and monocytes were exposed to 1 and $5 \mathrm{ng} / \mathrm{ml}$ of FGF23 to mimic uremic levels. In resting conditions, a non-significant induction of CYP27B1 expression could only be observed in THP1 cells $(p=0.07)$; CYP27B1 expression did not change in monocytes $(\mathrm{p}=$ 0.7). Immune signal-induced CYP27B1 expression was significantly blunted by the addition of FGF23, both in
RT-PCR and normalized to the geometric mean of three housekeeping genes (RPL27, HPRT and $\beta_{2}-M G$ ). Each bar represents the mean of four independent experiments, each performed in triplicate $( \pm$ SEM).

THP1 cells $(\mathrm{p}=0.02)$ and monocytes $(\mathrm{p}=0.03)$ (fig. 7 ). CYP24 was below the limit of detection in resting conditions and was not induced by FGF23 (data not shown).

\section{Effect of PCS and IndS on CYP27B1 Expression in Healthy Monocytes}

We finally investigated the effect of PCS and IndS on CYP27B1 expression in THP1 cells, cultured either under resting conditions or after immune stimulation. CYP27B1 expression was not affected in any of the experimental conditions (fig. 8, 9). Additionally, the influence of PCS and IndS on CYP27B1 and inflammatory cytokine production was investigated in healthy monocytes. Again, no significant changes were observed (fig. 10). Since these findings were in contrast to literature data $[14,15]$, further experiments were designed to verify whether these toxins actually enter the monocytes. Uptake of PCS or IndS was evaluated by quantifying intracellular levels of these toxins in THP1 cells as well as healthy monocytes cultured for $24 \mathrm{~h}$ in a culture medium containing high levels $(1 \mathrm{mM})$ of either toxin. Intracellular levels were below the limit of detection in all experiments. In line with this finding, we failed to find expression of organic anion transporters (OAT) 1 (monocyte $\mathrm{Ct}$ $39 \pm 2$ vs. renal tubular cell Ct 26 ) and OAT3 (monocyte Ct $38 \pm 4$ vs. renal tubular cell Ct 27) in monocytes. OAT1 and OAT3 are considered major transporters involved in the cellular uptake of PCS and IndS. 


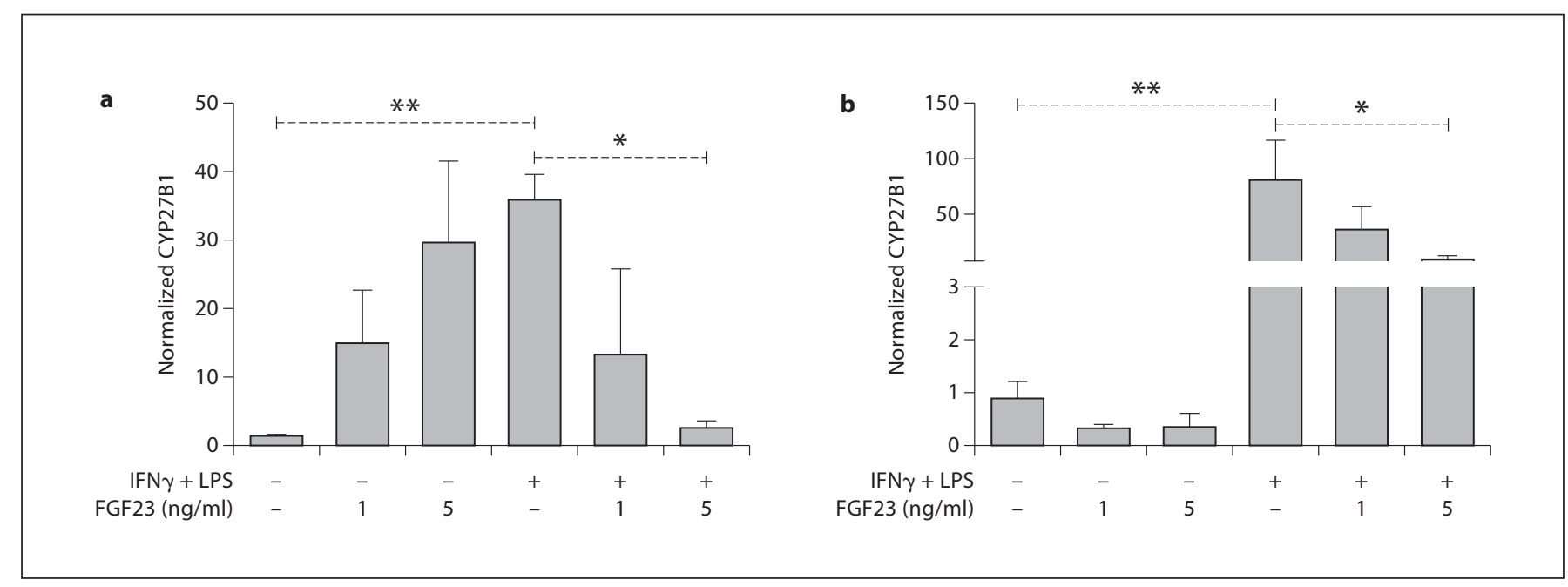

Fig. 7. Expression of CYP27B1 mRNA levels in THP1 cells (a) and monocytes (b). Monocytes and THP1 cells were cultured for $24 \mathrm{~h}$ with or without IFN $\gamma+$ LPS stimulation, in the presence/absence of 1 or $5 \mathrm{ng} / \mathrm{ml} \mathrm{FGF23.} \mathrm{CYP27B1} \mathrm{mRNA} \mathrm{levels} \mathrm{were} \mathrm{quantified} \mathrm{by}$ real-time RT-PCR and normalized to the geometric mean of three housekeeping genes (RPL27, HPRT and $\beta_{2}-\mathrm{MG}$ ). Each bar represents the mean of six samples ( \pm SEM). One-way ANOVA statistics were used with significant Duncan post hoc comparison marked with an asterisk. ${ }^{*} \mathrm{p}<0.05 ;{ }^{* *} \mathrm{p}<0.01$.

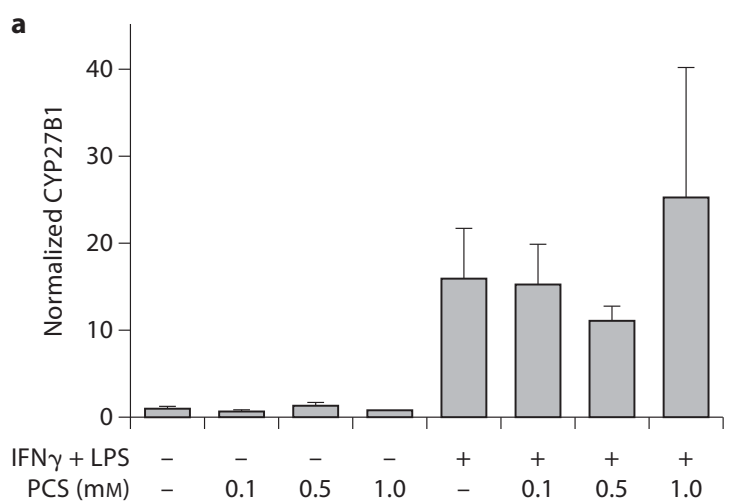

Fig. 8. Expression of CYP27B1 mRNA in THP1 cells. THP1 cells were cultured for $24 \mathrm{~h}$ with or without IFN $\gamma+$ LPS stimulation (IFN $\gamma 100 \mathrm{U} / \mathrm{ml}$ and LPS $10 \mu \mathrm{g} / \mathrm{ml}$ ), in the presence/absence of PCS $0.1,0.5$ or $1 \mathrm{~mm}$ (a) or IndS $0.1,0.5$ or $1 \mathrm{mM}$ (b). CYP27B1 mRNA

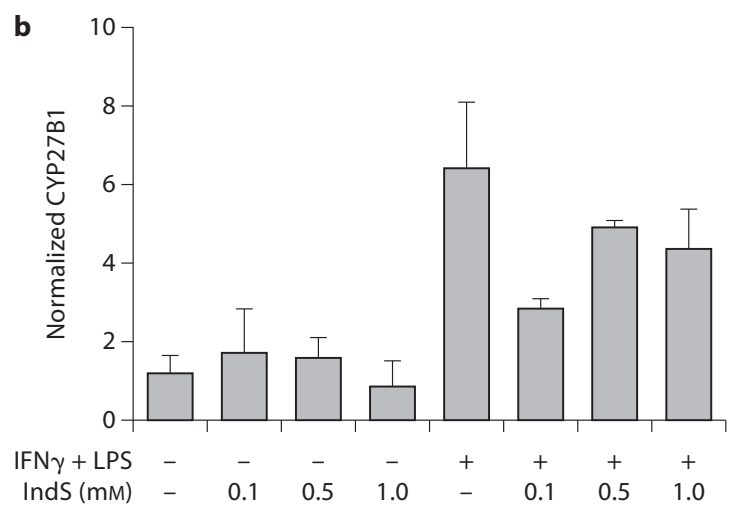

levels were quantified by real-time RT-PCR and normalized to the geometric mean of three housekeeping genes (RPL27, HPRT and $\left.\beta_{2}-M G\right)$. Each bar each represents the mean of four experiments, each performed in duplicate $( \pm$ SEM).

\section{Discussion}

Circulating $1,25(\mathrm{OH})_{2} \mathrm{D}$ levels are reduced in CKD patients and contribute to disturbances in mineral and bone metabolism. Locally produced $1,25(\mathrm{OH})_{2} \mathrm{D}$, on the other hand, is most probably responsible for many of the pleio- tropic health benefits that have been reported for vitamin $\mathrm{D}$ [25]. The present study was designed to elucidate the impact of uremia on local vitamin D metabolism. We thereby focused on monocytes, as these cells are critical components in the innate immune system and also play an important role in atherogenesis. Monocytes are not 


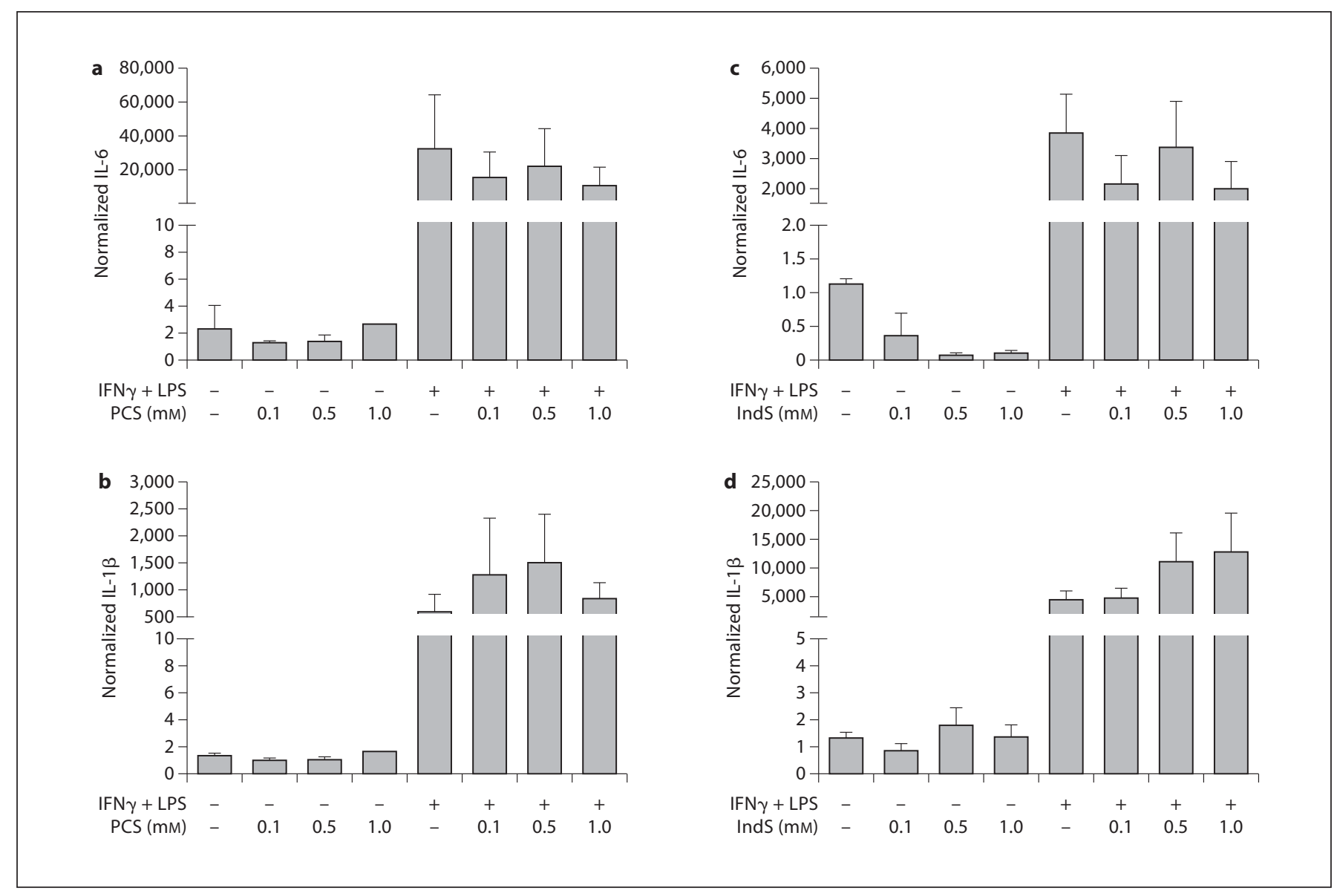

Fig. 9. Expression of IL- 6 and IL-1 $\beta$ mRNA levels in THP1 cells. THP1 cells were cultured for $24 \mathrm{~h}$ with or without IFN $\gamma+$ LPS stimulation (IFN $\gamma 100 \mathrm{U} / \mathrm{ml}$ and LPS $10 \mu \mathrm{g} / \mathrm{ml}$ ), in the presence/ absence of PCS $0.1,0.5$ or $1 \mathrm{mM}(\mathbf{a}, \mathbf{b})$ or IndS $0.1,0.5$ or $1 \mathrm{~mm}$ (c, d). IL- 6 and IL-1 mRNA levels were quantified by real-time RTPCR and normalized to RPL27 levels. Each bar represents the mean of four experiments, each performed in duplicate $( \pm S E M)$. only capable of responding to vitamin D metabolites in the presence of an inducible VDR, but also display the full machinery for local vitamin metabolism, including 25-hydroxylase (both CYP27A1 and CYP2R), 1 $\alpha$-hydroxylase (CYP27B1) and 24-hydroxylase (CYP24A1), the degrading enzyme [26-28].

In agreement with data reported by Dusso et al. [29], we demonstrate increased CYP27B1 mRNA expression and thus local $1,25(\mathrm{OH})_{2} \mathrm{D}$ production in monocytes from hemodialysis patients as compared to monocytes from healthy volunteers. Different from its renal counterpart, vitamin D metabolism in monocytes is regulated by immune stimuli [30]. Monocytic CYP27B1 expression is strongly upregulated by IFN $\gamma$, LPS and TLR-2/1 complex ligands $[26,27,30-32]$. Addition of uremic serum to the culture medium tended to increase the expression of $\mathrm{CY}$ -
P27B1 in monocytes from healthy volunteers. This finding suggests that a circulating factor may be involved. Given the microinflammatory state of uremia [33], proinflammatory mediators are the most likely mediator of the CYP27B1 upregulation. The present study does not allow us to exclude the possibility that defective feedback inhibition by low calcitriol levels in uremic serum is also involved [29]. The proinflammatory milieu is confirmed by the observation that the addition of uremic serum led to induction of inflammatory cytokine (IL- 6 and IL-1 $\beta$ ) expression in healthy monocytes. Uremic circulating factors may thus trigger an inflammatory amplification loop, in which monocytes play an important role $[34,35]$. At first sight, the observation of an increased CYP27B1 expression in uremic monocytes is contraintuitive. Indeed, local vitamin $\mathrm{D}$ production in monocytes is consid- 


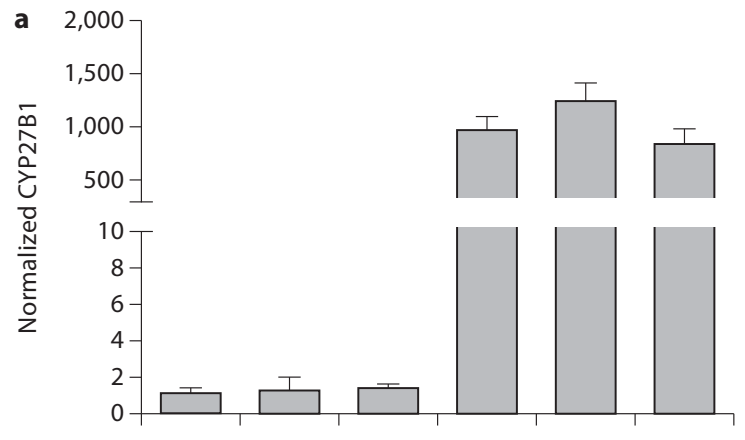

$\begin{array}{rcccccc}\mathrm{IFN} \gamma+\mathrm{LPS} & - & - & - & + & + & + \\ \mathrm{PCS} & - & 0.1 & 1.0 & - & 0.1 & 1.0\end{array}$

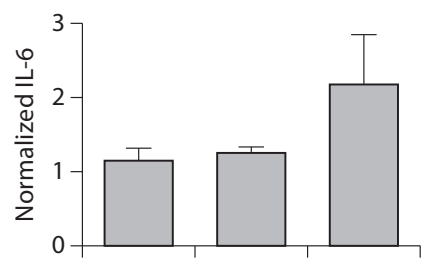

IFN $\gamma+$ LPS - $\quad-\quad-\quad-$

PCS - $\quad 0.1 \quad 1.0$

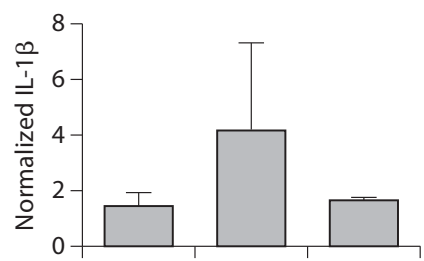

$\begin{array}{rrcc}\mathrm{IFN} \gamma+\mathrm{LPS} & - & - & - \\ \text { PCS } & - & 0.1 & 1.0\end{array}$

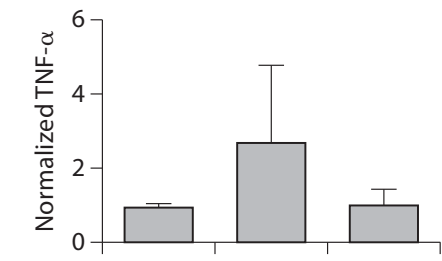

$\begin{array}{llll}\text { IFN } \gamma+\text { LPS } & - & - & -\end{array}$
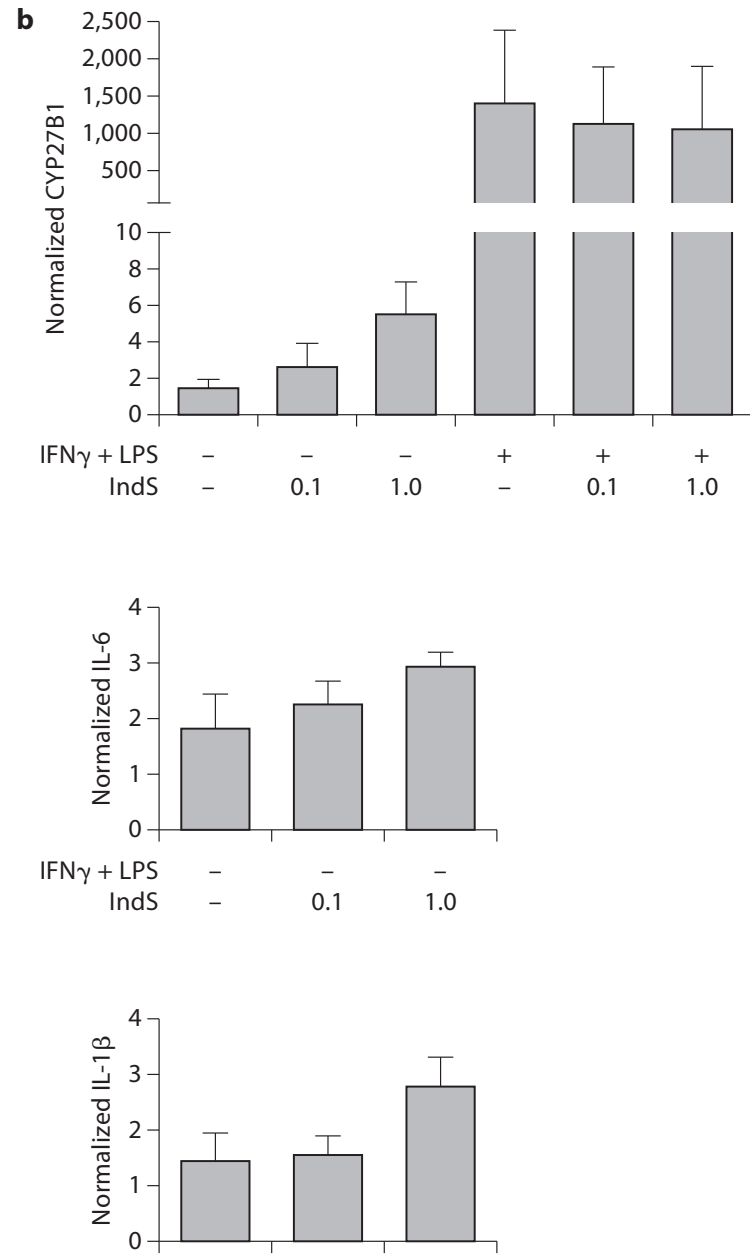

$\begin{array}{rrrr}\mathrm{IFN} \gamma+\mathrm{LPS} & - & - & - \\ \text { IndS } & - & 0.1 & 1.0\end{array}$

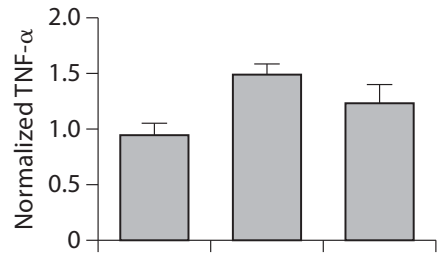

$\begin{array}{rccc}\mathrm{IFN} \gamma+\mathrm{LPS} & - & - & - \\ \text { IndS } & - & 0.1 & 1.0\end{array}$
Fig. 10. Expression of CYP27B1 and IL-6, IL-1 $\beta$ and TNF- $\alpha$ mRNA levels in monocytes. Monocytes were cultured for $24 \mathrm{~h}$ with or without IFN $\gamma+$ LPS stimulation (IFN $\gamma 12.5 \mathrm{U} / \mathrm{ml}$ and LPS $100 \mathrm{ng} / \mathrm{ml}$ ), in the presence/absence of PCS 0.1 or $1 \mathrm{mM} \mathrm{(a)}$ or IndS 0.1 or $1 \mathrm{mM}(\mathbf{b})$. CYP27B1 and inflammatory cytokines
mRNA levels were quantified by real-time RT-PCR and normalized to the geometric mean of three housekeeping genes (RPL27, HPRT and $\beta_{2}-M G$ ). Each bar represents the mean of three independent experiments, each performed in triplicate $( \pm$ SEM). 
ered to confer health benefits [36]. It should be emphasized that uncertainty persists as to whether this increased CYP27B1 expression in monocytes is paralleled by an increased local production. At least in the present study, local $1,25(\mathrm{OH})_{2} \mathrm{D}$ production in resting monocytes or THP1 cells was low. Local (monocytic) $1,25(\mathrm{OH})_{2} \mathrm{D}$ production is far more dependent on available $25(\mathrm{OH}) \mathrm{D}$ reserves than renal production $[6,7]$. Furthermore, CKD also impairs $25(\mathrm{OH}) \mathrm{D}$ uptake by monocytes [37]. Thus, even normal serum 25(OH)D levels may be insufficient to sustain 'autocrine/paracrine' $1,25(\mathrm{OH})_{2} \mathrm{D}$ actions in CKD. We speculate that circulating $25(\mathrm{OH}) \mathrm{D}$ levels in CKD patient are often inappropriately low and thereby preclude any significant local $1,25(\mathrm{OH})_{2} \mathrm{D}$ production despite maintained or even increased CYP27B1 expression.

In addition, we demonstrate that in contrast to the upregulation of CYP27B1 by uremia in resting monocytes, uremia suppresses the physiologic induction of CYP27B1 by natural immune stimuli such as IFN $\gamma$ and LPS. The altered CYP27B1 transcription was paralleled by changes in CYP27B1 enzyme activity. Local $1,25(\mathrm{OH})_{2} \mathrm{D}$ production is increasingly recognized to be critical for a normal functioning immune system. $1,25(\mathrm{OH})_{2} \mathrm{D}$, locally produced after an inflammatory challenge, not only stimulates innate immune responses but also modulates adaptive immune responses (towards tolerogenic rather than activated profiles) [36]. To the best of our knowledge, we are the first to report suppression of immune signal-induced CYP27B1 upregulation in uremia. The blunted local $1,25(\mathrm{OH})_{2} \mathrm{D}$ production could contribute to the wellknown increased susceptibility to infections in dialysis patients $[38,39]$. Infectious diseases represent the second leading cause of hospitalization and mortality in the endstage renal disease population.

Based on literature data, we raised the hypothesis that the protein-bound uremic retention solutes PCS and IndS $[14,15]$ and the phosphaturic hormone FGF23 [18] might be involved in this blunted immune signal-induced CYP27B1 expression in uremia. In the present study, we observed a significant downregulation of immune signal-induced CYP27B1 expression by FGF23 both in THP1 cells and monocytes. Some investigators have suggested a role for the protein-bound uremic retention molecules PCS and IndS in the monocyte activation $[14,15]$ and subsequent CYP27B1 upregulation. We failed however to demonstrate an effect of these uremic retention molecules on CYP27B1 expression, both in resting and immune-stimulated monocytes. It should be emphasized that in order to exert their toxic cellular effects, PCS and IndS need to be internalized. We demon- strated by two different approaches that intracellular transport of these toxins does not occur in monocytes as opposed to other cell types [40]. Altogether, our data indicate that PCS and IndS unlikely exert any effect on monocytes.

We are confident that the present study will fuel further research on the impact of uremia on extrarenal vitamin D metabolism. A better understanding of dysregulation may improve replacement therapy policies and optimize autocrine, beneficial functions of vitamin D.

In conclusion, monocytic CYP27B1 is upregulated in uremia, most probably as a reflection of the microinflammatory state in CKD. Immune signal-induced CYP27B1 expression and activity, conversely, is impaired in uremic conditions. Elevated FGF23 levels, but not PCS and IndS, may account, at least partly, for this impaired monocytic immune signal-induced CYP27B1 expression in uremia. A dysregulated local $1,25(\mathrm{OH})_{2} \mathrm{D}$ production in monocytes may contribute to the high cardiovascular and infectious burden in CKD.

\section{Acknowledgements}

This work was supported by a grant from the University of Leuven (GOA 2009/10) and a grant from the Flemish Research Foundation(Fonds VoorWetenschappelijkonderzoekG.0773.10N (P.E.)). C.M. has a clinical fellowship from the Flemish Research Foundation. We thank Marc Dekens, Eveline Vanhalewyck, Griet Lemmens and Kelly Verstraete for excellent technical assistance. The technical expertise of Ivo Jans for the measurement of $1,25(\mathrm{OH})_{2} \mathrm{D}$ production is greatly appreciated.

\section{Disclosure Statement}

The authors have no conflicts of interest to disclose.

References
Dusso AS, Tokumoto M: Defective renal maintenance of the vitamin D endocrine system impairs vitamin D renoprotection: a downward spiral in kidney disease. Kidney Int 2011;79:715-729.

2 Reichel H, Deibert B, Schmidt-Gayk H, Ritz $\mathrm{E}$ : Calcium metabolism in early chronic renal failure: implications for the pathogenesis of hyperparathyroidism. Nephrol Dial Transplant 1991;6:162-169.

3 Melamed ML, Astor B, Michos ED, Hostetter TH, Powe NR, Muntner P: 25-Hydroxyvitamin $\mathrm{D}$ levels, race, and the progression of kidney disease. J Am Soc Nephrol 2009;20: 2631-2639. 
4 Wolf M, Shah A, Gutierrez O, Ankers E, Monroy M, Tamez H, Steele D, Chang Y, Camargo CA Jr, Tonelli M, Thadhani R: Vitamin D levels and early mortality among incident hemodialysis patients. Kidney Int 2007;72:1004-1013.

$\checkmark 5$ Gonzalez EA, Sachdeva A, Oliver DA, Martin KJ: Vitamin D insufficiency and deficiency in chronic kidney disease. A single-center observational study. Am J Nephrol 2004;24: 503-510.

6 Vieth R: Vitamin D supplementation, 25-hydroxyvitamin D concentrations, and safety. Am J Clin Nutr 1999;69:842-856.

$\checkmark 7$ Heaney RP: Vitamin D in health and disease. Clin J Am Soc Nephrol 2008;3:1535-1541.

-8 Van Etten E, Stoffels K, Gysemans C, Mathieu C, Overbergh L: Regulation of vitamin D homeostasis: implications for the immune system. Nutr Rev 2008;66:S125-S134.

$\checkmark 9$ Meijers BK, Claes K, Bammens B, de Loor H, Viaene L, Verbeke K, Kuypers D, Vanrenterghem Y, Evenepoel P: $p$-Cresol and cardiovascular risk in mild-to-moderate kidney disease. Clin J Am Soc Nephrol 2010;5:11821189.

-10 Bammens B, Evenepoel P, Keuleers H, Verbeke K, Vanrenterghem Y: Free serum concentrations of the protein-bound retention solute $p$-cresol predict mortality in hemodialysis patients. Kidney Int 2006;69:10811087.

-11 De Smet R, Van Kaer J, Van Vlem B, De Cubber A, Brunet P, Lameire N, Vanholder R: Toxicity of free $p$-cresol: a prospective and cross-sectional analysis. Clin Chem 2003;49: $470-478$.

-12 Gutierrez OM, Mannstadt M, Isakova T, Rauh-Hain JA, Tamez H, Shah A, Smith K, Lee H, Thadhani R, Juppner H, Wolf M: Fibroblast growth factor 23 and mortality among patients undergoing hemodialysis. $\mathrm{N}$ Engl J Med 2008;359:584-592.

-13 Fliser D, Kollerits B, Neyer U, Ankerst DP, Lhotta K, Lingenhel A, Ritz E, Kronenberg F, for the MMKD Study Group: Fibroblast growth factor 23 (FGF23) predicts progression of chronic kidney disease: the Mild to Moderate Kidney Disease (MMKD) study. J Am Soc Nephrol 2007;18:2600-2608.

-14 Lekawanvijit S, Adrahtas A, Kelly DJ, Kompa AR, Wang BH, Krum H: Does indoxyl sulfate, a uraemic toxin, have direct effects on cardiac fibroblasts and myocytes? Eur Heart J 2010;31:1771-1779.

-15 Schepers E, Meert N, Glorieux G, Goeman J, Van der Eycken J, Vanholder R: p-Cresylsulphate, the main in vivo metabolite of $p$-cresol, activates leucocyte free radical production. Nephrol Dial Transplant 2007;22:592596.

-16 Saito H, Maeda A, Ohtomo Si, Hirata M, Kusano K, Kato S, Ogata E, Segawa H, Miyamoto Ki, Fukushima N: Circulating FGF-23 is regulated by $1 \alpha, 25$-dihydroxyvitamin $\mathrm{D}_{3}$ and phosphorus in vivo. J Biol Chem 2005; 280:2543-2549.
17 Hasegawa $\mathrm{H}$, Nagano N, Urakawa I, Yamazaki Y, Iijima K, Fujita T, Yamashita T, Fukumoto S, Shimada T: Direct evidence for a causative role of FGF23 in the abnormal renal phosphate handling and vitamin $\mathrm{D}$ metabolism in rats with early-stage chronic kidney disease. Kidney Int 2010;78: 975-980.

18 Faul C, Amaral AP, Oskouei B, Hu MC, Sloan A, Isakova T, Gutierrez OM, AguillonPrada R, Lincoln J, Hare JM, Mundel P, Morales A, Scialla J, Fischer M, Soliman EZ, Chen J, Go AS, Rosas SE, Nessel L, Townsend RR, Feldman HI, St John SM, Ojo A, Gadegbeku C, Di Marco GS, Reuter S, Kentrup D, Tiemann K, Brand M, Hill JA, Moe OW, Kuro O, Kusek JW, Keane MG, Wolf M: FGF23 induces left ventricular hypertrophy. J Clin Invest 2011;121:4393-4408.

$>19$ Feigenbaum J, Neuberg C: Simplified method for the preparation of aromatic sulfuric acid esters. J Am Chem Soc 1941;63:35293530 .

-20 Meijers BKI, Weber V, Bammens B, Dehaen W, Verbeke K, Falkenhagen D, Evenepoel P: Removal of the uremic retention solute $p$ cresol using fractionated plasma separation and adsorption. Artif Organs 2008;32:214219.

-21 Giulietti A, Overbergh L, Valckx D, Decallonne B, Bouillon R, Mathieu C: An overview of real-time quantitative PCR: applications to quantify cytokine gene expression. Methods 2001;25:386-401.

22 Casetta B, Jans I, Billen J, Vanderschueren D, Bouillon R: Development of a method for the quantification of $1 \alpha, 25(\mathrm{OH})_{2}$-vitamin $\mathrm{D}_{3}$ in serum by liquid chromatography tandem mass spectrometry without derivatization. Eur J Mass Spectrom (Chichester, Eng) 2010; 16:81-89.

23 De Loor H, Meijers BK, Meyer TW, Bammens B, Verbeke K, Dehaen W, Evenepoel P: Sodium octanoate to reverse indoxyl sulfate and $p$-cresyl sulfate albumin binding in uremic and normal serum during sample preparation followed by fluorescence liquid chromatography. J Chromatogr A 2009;1216: 4684-4688.

-24 Bouillon R, Van HE, Jans I, Tan BK, Van BH, De MP: Two direct (nonchromatographic) assays for 25-hydroxyvitamin D. Clin Chem 1984;30:1731-1736.

25 Holick MF: Vitamin D: A millennium perspective. J Cell Biochem 2003;88:296-307.

26 Overbergh L, Decallonne B, Valckx D, Verstuyf A, Depovere J, Laureys J, Rutgeerts O, Saint-Arnaud R, Bouillon R, Mathieu C: Identification and immune regulation of 25-hydroxyvitamin $\mathrm{D}_{1} \alpha$-hydroxylase in murine macrophages. Clin Exp Immunol 2000; 120:139-146.
27 Liu PT, Stenger S, Li H, Wenzel L, Tan BH, Krutzik SR, Ochoa MT, Schauber J, Wu K, Meinken C, Kamen DL, Wagner M, Bals R, Steinmeyer A, Zugel U, Gallo RL, Eisenberg D, Hewison M, Hollis BW, Adams JS, Bloom BR, Modlin RL: Toll-like receptor triggering of a vitamin D-mediated human antimicrobial response. Science 2006;311:1770-1773.

28 Stubbs JR, Idiculla A, Slusser J, Menard R, Quarles LD: Cholecalciferol supplementation alters calcitriol-responsive monocyte proteins and decreases inflammatory cytokines in ESRD. J Am Soc Nephrol 2010;21: 353-361.

29 Dusso AS, Finch J, Brown A, Ritter C, Delmez J, Schreiner G, Slatopolsky E: Extrarenal production of calcitriol in normal and uremic humans. J Clin Endocrinol Metab 1991; 72:157-164

30 Stoffels K, Overbergh L, Giulietti A, Verlinden L, Bouillon R, Mathieu C: Immune reg_ ulation of 25 -hydroxyvitamin- $D_{3}-1 \alpha$-hydroxylase in human monocytes. J Bone Miner Res 2006;21:37-47.

31 Esteban L, Vidal M, Dusso A: $1 \alpha$-Hydroxylase transactivation by $\gamma$-interferon in $\mathrm{mu}$ rine macrophages requires enhanced $\mathrm{C} /$ EBP $\beta$ expression and activation. J Steroid Biochem Mol Biol 2004;89-90:131-137.

>32 Overbergh L, Stoffels K, Waer M, Verstuyf A, Bouillon R, Mathieu C: Immune regulation of 25-hydroxyvitamin D-1 $\alpha$-hydroxylase in human monocytic THP1 cells: mechanisms of interferon- $\gamma$-mediated induction. J Clin Endocrinol Metab 2006;91:3566-3574.

33 Kaysen GA: The microinflammatory state in uremia: causes and potential consequences. J Am Soc Nephrol 2001;12:1549-1557.

>34 Schindler R, Boenisch O, Fischer C, Frei U: Effect of the hemodialysis membrane on the inflammatory reaction in vivo. Clin Nephrol 2000;53:452-459.

35 Stenvinkel P, Carrero JJ, Axelsson J, Lindholm B, Heimburger O, Massy Z: Emerging biomarkers for evaluating cardiovascular risk in the chronic kidney disease patient: how do new pieces fit into the uremic puzzle? Clin J Am Soc Nephrol 2008;3:505-521.

>36 Baeke F, Etten EV, Overbergh L, Mathieu C: Vitamin $\mathrm{D}_{3}$ and the immune system: maintaining the balance in health and disease. Nutr Res Rev 2007;20:106-118.

>37 Gallieni M, Kamimura S, Ahmed A, Bravo E, Delmez J, Slatopolsky E, Dusso A: Kinetics of monocyte $1 \alpha$-hydroxylase in renal failure. Am J Physiol 1995;268:F746-F753.

38 Dalrymple LS, Go AS: Epidemiology of acute infections among patients with chronic kidney disease. Clin J Am Soc Nephrol 2008;3: 1487-1493.

-39 Vanholder R, Van LA, Dhondt AM, De SR, Ringoir S: Influence of uraemia and haemodialysis on host defence and infection. Nephrol Dial Transplant 1996;11:593-598.

40 Niwa T: Indoxyl sulfate is a nephro-vascular toxin. J Ren Nutr 2010;20:S2-S6.
Viaene/Evenepoel/Meijers/

Vanderschueren/Overbergh/Mathieu 